\title{
Clipped Cowpea (Vigna unguiculata (L.) Walp) Fodder Utilization: A Potential for Income Growths of Resource Poor Farmers in the Savannah Regions of Nigeria
}

\author{
Banake E. Sambo ${ }^{1} \&$ Ehiabhi C. Odion ${ }^{2}$ \\ ${ }^{1}$ Department of Crop Science, Federal University Dutse, Jigawa State, Nigeria \\ ${ }^{2}$ Department of Agronomy, Institute for Agricultural Research, Ahmadu Bello University, Samaru, Zaria, \\ Nigeria \\ Correspondence: Banake E. Sambo, Department of Crop Science, Federal University Dutse, Jigawa State, \\ Nigeria. Tel: 234-802-330-8577. E-mail: banelisam@yahoo.com
}

\author{
Received: May 5, 2015 Accepted: July 15, 2015 Online Published: January 19, 2016 \\ doi:10.5539/sar.v5n1p70 \\ URL: http://dx.doi.org/10.5539/sar.v5n1p70
}

\begin{abstract}
Cowpea features prominently in the farming systems of the semi-arid tropics where they are grown for fodder used as feed for livestock. Traditional farm varieties are the indeterminate, spreading type which grow fast; cover the soil surface and produce large quantities of biomass. Studies have focused on the use of such green crop materials for soil fertility improvement. But, it's been highlighted that a green manure crop should also be a cover crop of economic value. Such crops should raise the farmers' income not only indirectly by improving soil fertility but also directly by yielding products of economic importance such as food and fodder. In addition, trading in these residues (fodder/ haulms) can be highly remunerating. It is against this background that this study was carried out at the Institute for Agricultural Research, Ahmadu Bello University, Samaru, Zaria, Nigeria; During the 2002-2005 wet seasons; to determining the influence of intra-row spacing, clipping height and time on the productivity and income growth potential of the dual purpose cowpea (Vigna unguiculata (L.) Walp). The experimental lay out was a Randomized Complete Block Design (RCBD); replicated three times. The data was analyzed statistically using the analysis of variance test (ANOVA); and the means compared using the Duncan Multiple Range Test (DMRT). Results showed that, clipping management, facilitated the production of large (15 $t h^{-1}$ ) amounts of green plant biomass on-farm. This could be put to various uses by the resource poor farmer who usually is cash strapped at the peak of the farming (dry) season. The farmer could choose to keep and use the fodder to feed animals, and/ or trade it off and use the proceeds ( 41,000.00 - $\$ 46,000.00$ - Nigerian Naira equivalent) to subsidize on fertilizer requirement and/ or meet up with immediate socio-economic family demands. Additionally, considering the high amount $\left(187 \mathrm{~kg}^{-1}\right)$ of $\mathrm{N}$-added to the soil (i.e. about 4 bags of Urea fertilizer), a cost saving of about $\$ 24,000.00$ was made by the resource poor farmer; which could have otherwise been invested into the procurement of $\mathrm{N}$-fertilizer input. It is concluded that such pro-poor income growths originating from the adoption of such innovative clipping management technological farming practices as this, needs to be encouraged and supported; as this hold immense potential of increasing the income of resource poor, low income, and low technology farmers. Indeed, it is a veritable tool for the reduction of food insecurity and poverty viz. economic empowerment in the region.
\end{abstract}

Keywords: clipped, fodder, on-farm, income, sustainable, growths, poverty, food insecurity

\section{Introduction}

Cowpea (Vigna unguiculata (L.) Walp) is a warm-weather annual crop. It withstands heat better than most other legumes and is very drought-resistant. The cowpea was originally native to Asia (Encarta, 2005); today, it is widely grown in mainly tropical parts of the world (Onwueme, 1979). It features prominently in the farming systems of the semi-arid tropics where they are grown for fodder, forage, hay, silage, as feed for livestock (Purseglove, 1974; Odion \& Singh, 2005b).

The photosensitive late maturing (85-120 days) fodder type that produces abundant vegetation as it spreads across the ground; and since it matures after the grown cereal crops, it is an important source of livestock feed during the long dry season; especially in West and Central Africa (International Institute for Tropical Agriculture, 
1992). Traditional farm varieties are the indeterminate, spreading type with a growing period of up to 120 days. They grow fast, cover the soil surface and produce large quantities of biomass which can be used as green manure. In the Sahel, green fodder yields approaching 30-40 $\mathrm{tha}^{-1}$ or 3-4t ha $\mathrm{a}^{-1}$ of dry weight have been reported (IITA, 1989). Odion and Singh (2005a) in their trials reported that when the total fodder yields were taken into consideration, (from both harvests added together) Kanannado in 1994, gave significantly higher $\left(5.11 \mathrm{t} \mathrm{ha}^{-1}\right)$ fodder than Kano 1696 (3.62 $\mathrm{t} \mathrm{ha}^{-1}$ ) in 1994 only. In addition, they reported that, in the years investigated, increasing clipping height from 0 to $22.5 \mathrm{~cm}$ increased the total fodder yield $\left(\mathrm{t} \mathrm{ha}^{1}\right)$ of Kano 1696 . However in the Guinea savannah region, Sambo, Odion, Aliyu, and Labe (2013) reported higher fresh (green) fodder yields of up to $15 \mathrm{tha}^{-1}$, under clipping management. In India, under the fodder production system; cowpea is planted at a row spacing of 40-50 cm; giving high fodder yield returns (harvested at 60-70 days from sowing); of 250-300 t ha $^{-1}$ (Patil \& Singh, 2004).

Green manure crops are generally not associated with a direct increase in income and if this is the case, then subsistence farmers are not likely to be interested in them. Therefore, for these farmers, a green manure crop should be a cover crop of economic value, such that the fodder is allowed to grow after the harvest of grains. Such a crop provides green manure (added soil organic matter - SOM) from its re-growth at the beginning of the next season. Thus, crops for green manure should raise the farmers income not only indirectly by improving soil fertility but also directly, that is, by yielding products of economic importance such as fuel, stakes for climbing plants, food, fodder and medicines (Reijntjes, Haverkort, \& Waters-Bayer, 1992; Odion, Asiribo, Ogunlela, Singh, \& Tarawali, 2007; Sambo \& Odion, 2011). Consequently, the above ground plant parts of cowpea, excepting for its pods, are usually harvested for fodder. In some areas, trading in these residues (haulms) can be highly remunerating. It is reported that in West and Central Africa, farmers who cut and store cowpea fodder, for subsequent sale at the peak of the dry season, have been found to obtain as much as $25 \%$ of their annual income by this means (IITA, 1989); sustainably.

In this regard, sustainable agriculture could be defined as a practice that involves the successful management of resources for agriculture to satisfy human needs, while maintaining or enhancing the quality of the environment and conserving natural resources (Food \& Agriculture Organization, 1989). Sustainable agriculture, on this basis, is now viewed from a systems perspective, in which the agro system interacts with the atmospheric system and the hydrological cycle as well as with the social and economic systems of the community where it is practiced (Scholes, Swift, Hewal, Sanchez, \& Ingran, 1994). One of such agricultural practices is the introduction of green plant residues into farming systems, with the attendant multi-beneficial effects (Tian, Kang, Akobundu, \& Manyond, 1994); which comes from understanding the biochemical process involved in symbiotic N-fixation. The advantage of the above stated practice is in its ability to sustain crop productivity through enhancing soil fertility. In the semi-arid regions with its inherent low soils fertility status, this could be pivotal to sustaining production levels. With the improvement in the fertility status of the soils, high fodder yields can be obtained. Indeed, forage legume crops as cowpea, can be clipped for sustained fodder yield and economic return (Eckert \& Hall, 1991).

In line with these postulations, this study was conducted with the aim of determining the total amount of fodder produced and the extra income that could be made from the sales of this harvested (clipped) fresh fodder; and the savings that could be made (in Nigerian Naira - $N$ - equivalent) considering the amount of $\mathrm{N}$-added/ or gained by the soil.

\section{Materials and Methods}

Field experiments were carried out on the research farm of the Institute for Agriculture Research, Samaru, Nigeria, during the 2002, 2003, 2004 and 2005 cropping seasons. Samaru $\left(11^{\circ} .11^{\prime} \mathrm{N}, 07^{\circ} .38^{\prime} \mathrm{E}\right.$ and $686 \mathrm{~m}$ above sea level) is located in the northern Guinea savanna agro-ecology of Nigeria (Keay, 1959). Usually, rainfall in the region becomes well established between mid-May and early June and peaks in July/August. Total annual rainfall ranges between $883-1062 \mathrm{~mm}$, with an average of $945.20 \mathrm{~mm}$. The dry season starts at about mid-October and extends to the end of April. The mean minimum and maximum temperatures during the rainy seasons range between $14-22{ }^{\circ} \mathrm{C}$ and $29-34{ }^{\circ} \mathrm{C}$, respectively. The soil of the experimental site at the beginning of the trials in 2002 was loamy characterized by a $\mathrm{pH}$ of 6.60 ; low organic carbon content low organic carbon content $\left(0.299 \mathrm{~g} \mathrm{~kg}^{-1}\right)$; and low nitrogen $\left(0.087 \mathrm{~g} \mathrm{~kg}^{-1}\right)$; a phosphorus value of $6.51 \mathrm{mg} \mathrm{kg}^{-1}$ and a low level of potassium $\left(0.10 \mathrm{cmol} \mathrm{kg}^{-1}\right)$.

The treatments comprised of three intra-row spacing, 15.0, 30.0 and $45.0 \mathrm{~cm}$ on ridges $75 \mathrm{~cm}$ apart; three clipping heights (no clipping control $-0,12.5 \mathrm{~cm}$ and $25.0 \mathrm{~cm}$ ); and three clipping periods $(64,74$ and 84 days after planting - DAP) respectively. Factorial combinations of these treatments were laid out in a Randomized 
Complete Block Design (RCBD); replicated three times.

The land was ploughed and harrowed twice using mechanical power to give a good soil tilt; then ridged and demarcated into a gross and net plot sizes of $9.0 \mathrm{~m}^{2}$ and $4.5 \mathrm{~m}^{2}$ respectively. Two seeds of cowpea were planted per hole at about $5 \mathrm{~cm}$ depth.

The variety was used (Kano 1696/ Sampea 6), is a highly photosensitive dual purpose cowpea, which is usually planted late in the season for fodder as well as grains when possible. It is late maturing (100-120 days), and has a spreading habit; growing vegetative with little grain yield $\left(250-1000 \mathrm{~kg} \mathrm{ha}^{-1}\right)$ production. It produces long pods, extra large white seed with black eye, rough seed coat texture and has good palatability.

Fertilizer was applied at the recommended rate of $10 \mathrm{~kg} \mathrm{~N} \mathrm{ha}^{-1,} 36 \mathrm{~kg} \mathrm{P}_{2} \mathrm{O}_{5} \mathrm{ha}^{-1}$ and $20 \mathrm{~kg} \mathrm{~K}_{2} \mathrm{O} \mathrm{ha}^{-1}$ (Enwezor, Udo, Usoroh, Ayotade, Adepetu, \& Chude, 1989). Weeds were controlled at planting using Gramazone (Paraquat) as a pre and post emergence herbicide; supplemented with manual weeding operations. Post-emergence protection against insect pest and fungal attacks were provided using the insecticides and fungicides as and when necessary.

The fields were planted on $13^{\text {th }}$ July, $17^{\text {th }}$ July, $7^{\text {th }}$ June and $17^{\text {th }}$ June, in 2002, 2003, 2004 and 2005 respectively. The cowpea crop was clipped (harvested) at 64,74 and 84 days after planting (DAP). The first clipping was done on $15^{\text {th }}$ September, 2002; $19^{\text {th }}$ September, 2003; $10^{\text {th }}$ August, 2004, and $17^{\text {th }}$ August, 2005, respectively. The clipped fodder was placed on the plots to decay and act as a source of organic manure. The clipped plants were then left to grow to maturity alongside the control (unclipped) plots for further growth and yield analysis.

Clipped fodder yield $\left(\mathrm{t} \mathrm{ha}^{-1}\right)$ : The clipped fodder yield was obtained by weighing and recording the total clipped crop residue (fodder) from each plot; then converted to total fodder yield in tons per hectare $\left(\mathrm{t} \mathrm{ha}^{-1}\right)$ basis.

Soil nutrient analysis: A $5 \mathrm{~g}$ fair dry soil was taken and analyzed for the soil chemical properties including soil -N, according to the standard procedures as described by (Black, 1965; Day, 1965; IITA, 1975; Bray \& Kuntz, 1945; Kundsen, Peterson, \& Paratt, 1982).

Total nitrogen $(\mathrm{N})$ value added to soil: The total amount of $\mathrm{N}$ added by dual purpose cowpea, into the soil during the four-year experimental period (2002-2005) was determined and converted to total amount of $\mathrm{N}$ in kg ha-1 [taking into account the soil surface bulk density for Samaru; depth of soil sample; volume of soil (area per hectare) $\times$ depth); weight of soil (volume $\times$ bulk density)]. Urea $(40 \%)$ fertilizer was used to compute the total $\mathrm{N}$-contained in a $50 \mathrm{~kg}$ bag. The cost of a $50 \mathrm{~kg}$ bag of urea fertilizer in the open market during the experimental period was averaged at $\$ 3,300$ (Nigerian Naira equivalent). Therefore, from the known amount of $\mathrm{N}$ - contained in a $50 \mathrm{~kg}$ bag of urea and the total amount of $\mathrm{N}$ added to the soil, a cost analysis was conducted to determine the amount in Nigerian Naira saved in cost that would have otherwise been invested in the procurement of $\mathrm{N}$ -fertilizer inputs by the resource poor farmer.

Harvested fresh fodder yield $\left(\mathrm{t} \mathrm{ha}^{-1}\right)$ : The total harvested fresh fodder yield obtained per plot and converted to tons per hectare was evaluated (using a mean open market value put at about $\$ 200.00$ per $50 \mathrm{~kg}$ weight of cowpea fresh fodder during the experimental period) to determine the extra cost benefit in Nigerian Naira equivalent, that that could accrue from the sale of this fresh fodder to the resource poor farmer apart from his additional grain yield. The net margin of income from harvested fresh fodder yield sales i.e. income above cost of production input such as cost of land preparation, fertilizer, chemicals, planting, weeding and other labor costs, etc., were calculated assuming the yearly input cost levels.

The data collected was compiled and analyzed statistically using the analysis of variance test (F-test) as described by (Snedecor \& Cochran 1967). The means were compared using the Duncan Multiple Range Test-DMRT (Duncan, 1955).

\section{Results}

\subsection{Harvested Fresh Fodder Yield}

The intra-row spacing had a significant influence on fresh fodder yield in 2002, 2005 and combined analysis for 2002-2005. In 2002, fresh fodder yield significantly decreased with increasing intra-row spacing from 15 to 45 $\mathrm{cm}$. In 2005 and the combined analysis for 2002-2005, fresh fodder yield was significantly higher at $15 \mathrm{~cm}$ intra-row spacing than at 30 and $45 \mathrm{~cm}$ intra-row spacing; which were in turn statistically at par with each other (Table 1). Clipping height had no significant influence on harvested fresh fodder yield throughout the study period. Clipping time had a significant effect on fresh fodder yield in 2002, 2003, 2005 and the combined analysis for 2002-2005. In all these years, except in 2003, harvested fresh fodder produced from plots clipped at 74 and 84 DAP were statistically the same; but significantly higher than the fresh fodder obtained from plots 
clipped at 64 DAP. In 2003, fresh fodder yield obtained at 64 and 74 DAP were statistically at par; but significantly higher than that clipped at 84 DAP.

Table 1. Harvested fresh fodder yield $\left(\mathrm{t} \mathrm{ha}^{1}\right)$ as influenced by intra-row spacing, clipping management and time treatment at Samaru, Zaria-Nigeria

\begin{tabular}{llllll}
\hline Treatment & $\mathbf{2 0 0 2}$ & $\mathbf{2 0 0 3}$ & $\mathbf{2 0 0 4}$ & $\mathbf{2 0 0 5}$ & Combined 2002-2005 \\
\hline Intra-row spacing(cm) & & & & & \\
15 & $42.86 \mathrm{a}$ & 1.19 & 12.75 & $19.03 \mathrm{a}$ & $18.96 \mathrm{a}$ \\
30 & $29.88 \mathrm{~b}$ & 1.17 & 12.95 & $11.81 \mathrm{~b}$ & $13.95 \mathrm{~b}$ \\
45 & $19.05 \mathrm{c}$ & 1.03 & 12.67 & $12.98 \mathrm{~b}$ & $11.43 \mathrm{~b}$ \\
$\mathrm{SE} \pm$ & 2.90 & 0.17 & 0.86 & 1.97 & 0.93 \\
Clipping height (cm) & & & & & \\
0 (Control-unclipped) & - & - & - & - & - \\
12.5 & 30.26 & 1.29 & 12.83 & 16.48 & 15.22 \\
25.0 & 30.93 & 0.98 & 12.74 & 12.74 & 14.35 \\
$\mathrm{SE} \pm$ & 2.90 & 0.17 & 0.86 & 1.97 & 0.93 \\
Clipping time (DAP) & & & & & \\
64 & $7.64 \mathrm{~b}$ & $0.78 \mathrm{~b}$ & 11.45 & $9.33 \mathrm{~b}$ & $7.30 \mathrm{~b}$ \\
74 & $43.66 \mathrm{a}$ & $0.98 \mathrm{~b}$ & 13.10 & $19.50 \mathrm{a}$ & $19.31 \mathrm{a}$ \\
84 & $40.49 \mathrm{a}$ & $1.64 \mathrm{a}$ & 13.80 & $15.00 \mathrm{a}$ & $17.73 \mathrm{a}$ \\
$\mathrm{SE} \pm$ & 2.90 & 0.17 & 0.86 & 1.97 & 0.93 \\
\hline
\end{tabular}

Means followed by different letter (s) are significantly different at 5\% level of Probability; using Duncan's Multiple Range Test (DMRT).

\subsection{Economic Benefits in Nigerian Naira (\#) Equivalent}

\subsubsection{Net Margin of Income from Harvested Fresh Fodder}

Intra-row spacing had a significant effect on the net margin of income from fresh fodder yield sales in 2002, 2005 and the combined analysis for 2002-2005 (Table 2). In 2002 and the combined analysis for 2002-2005, the net margin of income decreased with increasing intra-row spacing from 15 to $45 \mathrm{~cm}$. In 2005, the net income at $15 \mathrm{~cm}$ intra-row spacing was significantly higher than at 30 and $45 \mathrm{~cm}$; which were statistically similar with each other. The height of clipping had a significant influence on the net margin of income from harvested fresh fodder yield sales in 2005 only. Here, plants clipped at $12.5 \mathrm{~cm}$ height generated significantly higher net margin of income than those clipped at $12.5 \mathrm{~cm}$ height. Clipping time significantly influenced the net margin of income from harvested fresh fodder yield sales in all the years of this study and the combined analysis for 2002-2005. The net income generated when the plants were clipped at 74 and 84 DAP, was statistically similar, and significantly higher than was realized at 64 DAP. Except in 2005 when the net income generated at 84 DAP and at 64 DAP, were statistically similar. The net margin of income in 2003, were all negative.

\subsection{Total Amount of Nitrogen Added to Soil}

Intra-row spacing and clipping time had no significant influence on the total amount of N-added to the soil during the four year period (2002-2005). Clipping height had a significant effect on the total amount of $\mathrm{N}$-added to the soil. Plots clipped at 12.5 and $25.0 \mathrm{~cm}$ heights, were statistically at par, but added significantly more $\mathrm{N}$ than the control (Table 3).

\subsection{Financial Gain in Nigerian Naira (\#) Equivalent From Total Nitrogen Added to the Soil}

Intra-row spacing and the time of clipping, did not have any significant effect on the economic benefit from the total amount of $\mathrm{N}$ gained during the period of this investigation. The influence of clipping height on the economic return from total amount of $\mathrm{N}$ gained during the period, 2002-2005, was significant. The result showed that the economic gain in Nigerian Naira ( $\$$ when plots were clipped at 12.5 and $25.0 \mathrm{~cm}$ heights were statistically at par; but significantly higher than the control plots (Table3). 
Table 2. Presents the net income from dual purpose cowpea harvested fresh fodder yield sales in Nigerian Naira ( equivalent as influenced by intra-row spacing, clipping management and time treatment at Samaru, Zaria - Nigeria

\begin{tabular}{llllll}
\hline Treatment & $\mathbf{2 0 0 2}$ & $\mathbf{2 0 0 3}$ & $\mathbf{2 0 0 4}$ & $\mathbf{2 0 0 5}$ & Combined 2002-2005 \\
\hline Intra-row spacing(cm) & & & & & \\
15 & $164,779 \mathrm{a}$ & - & 34,293 & $53,364 \mathrm{a}$ & $56,946 \mathrm{a}$ \\
30 & $120,773 \mathrm{~b}$ & - & 34,956 & $37,068 \mathrm{~b}$ & $42,161 \mathrm{~b}$ \\
45 & $88,523 \mathrm{c}$ & - & 33,671 & $33,179 \mathrm{~b}$ & $32,857 \mathrm{c}$ \\
$\mathrm{SE} \pm$ & 13,804 & - & 4,086 & 9,734 & 4,345 \\
Clipping height (cm) & & & & & \\
0 (Control-unclipped) & - & - & - & - & - \\
12.5 & 121,309 & - & 34,154 & $52,407 \mathrm{a}$ & 46,119 \\
25.0 & 128,074 & - & 34,459 & $30,000 \mathrm{~b}$ & 41,859 \\
$\mathrm{SE} \pm$ & 13,804 & - & 4,086 & 9,734 & 4,345 \\
Clipping time (DAP) & & & & & \\
64 & $46,688 \mathrm{~b}$ & - & $29,617 \mathrm{~b}$ & $24,846 \mathrm{~b}$ & $18,912 \mathrm{~b}$ \\
74 & $167,188 \mathrm{a}$ & - & $35,865 \mathrm{a}$ & $55,031 \mathrm{a}$ & $58,356 \mathrm{a}$ \\
84 & $160,220 \mathrm{a}$ & - & $37,437 \mathrm{a}$ & $43,735 \mathrm{ab}$ & $54,698 \mathrm{a}$ \\
$\mathrm{SE} \pm$ & 13,804 & - & 4,086 & 9,734 & 4,345 \\
\hline
\end{tabular}

Means followed by different letter (s) are significantly different at 5\% level of Probability; using Duncan's Multiple Range Test (DMRT).

Table 3. Presents the total nitrogen (N) gained/or added to the soil $\left(\mathrm{kg} \mathrm{ha}^{1}\right)$ in the period (2002-2005) converted to Nigerian Naira (N) equivalent as influenced by intra-row spacing, clipping management and time treatment at Samaru, Zaria - Nigeria

\begin{tabular}{|c|c|c|}
\hline \multirow[t]{2}{*}{ Treatment } & $\begin{array}{l}\text { Nitrogen gained/added to soil } \\
\left(\mathrm{Kg} \mathrm{ha}^{-1}\right)\end{array}$ & $\begin{array}{l}\text { Nitrogen added to soil converted to } \\
\text { Nigerian Naira equivalent }(\mathbb{N})\end{array}$ \\
\hline & Combined 2002-2005 & Combined 2002-2005 \\
\hline \multicolumn{3}{|c|}{ Intra-row spacing (cm) } \\
\hline 15 & 144.97 & $18,912.70$ \\
\hline 30 & 142.60 & $18,600.60$ \\
\hline 45 & 142.18 & $18,527.90$ \\
\hline $\mathrm{SE} \pm$ & 1.72 & 112.85 \\
\hline \multicolumn{3}{|c|}{ Clipping height (cm) } \\
\hline 0 (Control) & $55.59 \mathrm{~b}$ & $7,245.90 b$ \\
\hline 12.5 & $186.93 \mathrm{a}$ & $24,370.40 \mathrm{a}$ \\
\hline 25.0 & $187.23 \mathrm{a}$ & $24,424.90 \mathrm{a}$ \\
\hline $\mathrm{SE} \pm$ & 1.72 & 112.85 \\
\hline \multicolumn{3}{|c|}{ Clipping Time (DAP) } \\
\hline 64 & 142.82 & $18,709.50$ \\
\hline 74 & 143.43 & $18,699.50$ \\
\hline 84 & 143.50 & $18,632.30$ \\
\hline $\mathrm{SE} \pm$ & 1.72 & 112.85 \\
\hline
\end{tabular}

Means followed by different letter(s) are significantly different at $5 \%$ level of probability using Duncan's Multiple Range Test (DMRT). 


\section{Discussion}

\subsection{Economic Advantages of Clipping Management and Use of Cowpea Fodder}

The net margin of income (financial gain) that accrued from the sale of harvested fresh fodder yields of cowpea showed that, the net margin income was highest $(56,000.00)$ at the closest $(15 \mathrm{~cm})$ intra-row spacing. The net margin was $24 \%$ and $39 \%$ higher at $15 \mathrm{~cm}$ intra-row spacing than at 30 and $45 \mathrm{~cm}$ respectively. The highest income obtained at $15 \mathrm{~cm}$ intra-row spacing can be attributed to the fact that higher yield per area are reportedly achieved through greater population pressure (Willey \& Osiru, 1972; Beets, 1982). Also, a higher net margin was obtained when the crop was clipped at $12.5 \mathrm{~cm}$ ( $46,000.00)$ height. This translated to a $10.0 \%$ net increase in income compared to plants clipped at $25.0 \mathrm{~cm}$ height. The little added advantage in net income gained with clipping at shorter stem heights could be attributed to the added vine length viz., plant biomass that accompanied clipping the crop at shorter stem heights. The highest net income was recorded at 74 DAP ( $\$ 58,000.00)$; this was $68 \%$ higher than at 64 DAP. This can be explained by the fact that clipping at 74 DAP, coincided with the period of maximum vegetative growth attained by the crop (Musa, 1990).

The findings of this investigation has further shown that generally, substantial financial gains can be made by the resource poor farmer who often than not, has far depleted the family income at the height of the farming season and is in dare need of funds to meet up with other farms operational and family economic activities at the peak of the dry season. This is in conformity with Singh, Mohan-Raj, Dashiell, and Jackai (1997) who reported that farmers who cut and store cowpea fodder, for subsequent sale at the peak of the dry season, have been found to obtain as much as $25 \%$ of their annual income by this means. This is an added bonus, aside the final grain yield at harvest; which, could more than compensate for the little grain yield gained (Webster \& Wilson, 1980; Lee \& Wani, 1988; Muller-Samann \& Kotschi, 1994; Arevalo, Alegre, Bandy, \& Szolt, 1998; Badejo \& Togun, 2004; Odion \& Singh, 2005a, 2005b; Sambo, 2009; Sambo \& Odion, 2011).

Furthermore, the addition of clipped crop residue, apart from generally improving the soil quality, aided soil fertility and the most important effect, is the increase in the available N-content of the soil, through the production of relatively large amounts of green biomass on- site and for on-farm circulation, through nutrient release coming from the decomposition of organic crop residues with relatively low carbon: nitrogen $(\mathrm{C}: \mathrm{N})$ ratio. The advantage here is that, the maintenance (or increase) in soil fertility is based on the farmer's own resources (and less capital input is required); through the total $\mathrm{N}$ gained by the soil. The total soil- $\mathrm{N}$ enrichment in the four year period (2002-2005) of this investigation was between $142-187 \mathrm{~kg} \mathrm{~N} \mathrm{ha}^{-1}$ (i.e. about four $50 \mathrm{~kg}$ bags of Urea fertilizers); this translated to an annual mean value of $35-47 \mathrm{~kg} \mathrm{ha}^{-1}$. There was a remarkable $70 \%$ increase in soil $\mathrm{N}$-content when the plots were clipped and the clipped crop material added to the soil compared to the control. The significant contribution of cowpea to soil $\mathrm{N}$ levels has been documented. The total amount of $\mathrm{N}$-fixation by the cowpea crop is put between 70-350 $\mathrm{kg} \mathrm{ha}^{-1}$ (Singh et al., 1997). Muller-Samann \& Kotschi (1994) reported a mean value of $198 \mathrm{~kg} \mathrm{ha}^{-1}$ per year. And when this total $\mathrm{N}$ - gained by the soil in the period (2002-2005) was converted to monetary (financial) terms, the result showed that a total value of $\$ 18,000.00-\$ 24,000.00$ was gained from added soil-N; and/ or saved. This could potentially save the resource poor farmer about $70 \%$, in terms of the financial cost requirement, which would have otherwise being needed and/ or used to procure $\mathrm{N}$-fertilizer inputs (Sambo, 2009; Sambo \& Odion, 2011). These findings are in conformity with those of Eckert and Hall (1991), who reported that forage legumes can be clipped for sustained yield and economic return.

\section{Conclusion}

From the results of these findings, it can be concluded that this innovative clipping management technology facilitates the production of large amounts of green plant organic material (fresh fodder) on-farm which can be put to various uses. Ii could be added to the soil for soil fertility improvements; or economically, the resource poor farmer - cash strap at the peak of the farming season, could choose to keep and use the fodder to feed his animals at the peak of the dry season, and/ or sale it off and use the proceeds to meet up with his immediate personal socio-economic family needs. Indeed, this are implied savings that would have otherwise been used for the procurement of $\mathrm{N}$ fertilizers by the resource poor farmer. Without a doubt, such pro-poor income growths originating from the adoption of innovative clipping management technological practices as this need to be encouraged and supported; as this has the potential of reducing food insecurity and poverty for these low technology/ low inputs, resource poor, subsistence farmers in the region.

\section{References}

Arevalo, L. A., Alegre, J. C., Bandy, D. E., \& Szolt, L. T. (1998). The Effect of Cattle Grazing on Soil Physical and Chemical Properties in a Silvopastoral System in the Peruvian Amazon. Agro forestry System, 40, 109-124. In M. A. Badejo \& A. O. Togun (Eds.), Strategies and Tactics of Sustainable Agriculture in the 
Tropics (Vol. 2, pp. 1-226). College Press \& Publishers Ltd; Ibadan, Nigeria. http://dx.doi.org/10.1023/A:1006075114659

Badejo, M. A., \& Togun, A. O. (2004). Strategies and Tactics of Sustainable Agriculture in the Tropics (Vol. 2., pp. 1-226), College Press and Publishers Ltd., Ibadan, Nigeria.

Beets, W. C. (1982). Multiple Cropping and Tropical Farming Systems (p. 156). Aldershot, Gower.

Black, C. A. (1965). Methods of Soil Analysis. 11 Chemical and Microbial Properties (p. 1578). Madison, Wisconsin, American Society of Agronomy.

Bray, R. H., \& Kurtz, L. T. (1945). Determination of Total Organic and Available Forms of P in soil. Soil Science, 59, 39-45. http://dx.doi.org/10.1097/00010694-194501000-00006

Day, P. L. (1965). Particle Fractionation and Particle Size Analysis. In C. A. Black (Ed.), Method of Soil Analysis part 1. Physical and Mineralogical Properties. American Society of Agronomy, 545-567.

Duncan, D. B. (1955). Multiple Range and Multiple F-tests. Biometrics, 11, 1-42. http://dx.doi.org/10.2307/3001478

Eckert, J. W., \& Hall, M. H. (1991). Harvest Management of Alfalfa for Sustain Yield, Quality and Economic Return. Agronomy Abstracts, Annual Meeting.

Encarta. (2005). Cowpea: Reference Library Premium. Retrieved from http://www.cigiar.org/research/rescowpea.html

Enwezor, W. O., Udo, E. J., Usoroh, N. J., Ayotade, K. A., Adepetu, J. A., Chude, V. O., \& Udegbe, C. I. (Eds.) (1989). Fertilizer Use and Management Practices for Crops in Nigeria. Fertilizer Procurement and Distribution Division of the Federal Ministry of Agriculture, Water Resource, Rural Development (pp. 1-168). Lagos, Nigeria.

Food and Agriculture Organization. (1989). Sustainable Agriculture Production: Implications or International Agricultural Research. Technical Advisory Committee, CGIAR. FAO Research and Technical Paper No. 4. Rome, Italy: FAO. In P. L. Woomer \& M. J. Swift (Eds.), Biological Management of Tropical Soil Fertility (pp. 1-14). John Wiley and Sons, New York: Tropical Soil Biology and Fertility Progamme (TSBF) and Sayce Publishing (United Kingdom).

International Institute for Tropical Agriculture. (1989). Cowpea Research at International Institute for Tropical Agriculture (IITA). GLIP Research Monograph No.1 Ibadan, Nigeria.

International Institute for Tropical Agriculture. (1975). Selected Method for Soil and Plant Analysis. International Institute for Tropical Agriculture (IITA), Ibadan, Nigeria. Annual Report.

International Institute for Tropical Agriculture. (1992). Sustainable Food Production in Sub-Saharan Africa 1. IITA contributions. International Institute for Tropical Agriculture - IITA, Ibadan Nigeria.

Keay, R. W. J. (1959). An Outline of Nigerian Vegetation. (3rd Ed.) Government Printer, Lagos. In B. T. Kang, I. O. Akobundu, V. M. Manyong, R. J. Carsky, N. Sanginga, \& E. A. Kueneman (Eds.), Moist Savannas of Africa; Potentials and Constraints for Crop Production. Proceedings of an IITA/FAO Workshop held from 19-23 September, Cotonou, Republic of Benin, 1994. pp. 31-48.

Lee, K. K., \& Wani, S. P. (1988). Soil Fertility and Fertilizer Management in Semi arid Tropical India. Colloguium on Soil Fertility and Fertilizer Management in Semi arid Tropical India. Proceedings held 10/17-18/88, in Hyderabad, India. IFDC-Nlabama, U.S.A.

Kundsen, D., Peterson, G. A., \& Paratt, P. F. (1982). Lithium, Sodium and Potassium. In Pagered, A. L. (Ed.), Method of Soil Analysis. American Society of Agronomy, 225-246.

Muller-Samann, K. M., \& Kotschi, J. (1994). Sustaining Growth, Soil Fertility Management in Tropical Small Holding.CTA; GTZ-Weikersheim: Margra; Germany.

Musa, U. T. (1990). Effect of Seed Size and Phosphorus Level on the Growth and Yield of Cowpea (Vigna unguiculata (L.) Walp) varieties. M.Sc. Agronomy Seminar. Department of Agronomy, Ahmadu Bello University, Zaria, Nigeria. $14^{\text {th }}$ Sept. 1990.

Odion, E. C., \& Singh, B. B. (2005a). Production Dual Purpose Cowpea Varieties at Two Clipping Heights in the Sudan Savanna of Nigeria: 1. Fodder Production in Pure Stand. Journal of Arid Agriculture, 15, 9-14.

Odion, E. C., \& Singh, B. B. (2005b). Production of Dual Purpose Cowpea Varieties at two Clipping Heights in the Sudan Savanna of Nigeria 2. Pod and grain Production in Pure Stand. Journal of Arid Agriculture, 15, 
15-19.

Odion, E. C., Asiribo, O. E., Ogunlela, V. B., Singh, B. B., \& Tarawali, S. A. (2007). Strategies to Improve and Sustain Food Production Capacity in the Savannah: The Role of Leguminous Fodder Crops in Maintaining Soil Fertility and Health. Journal of Food, Agriculture and Environment, 5(2), 338-344.

Onwueme, I. C. (1979). Cassell's Tropical Agriculture Series (Book 2 Science, pp. 56-61). Macmillan Publishing Co. Inc. N.Y.

Patil, B. D., \& Singh, S. A. (2004). Forage Crops and Grasses. In C. S. Viswanath (Ed.), Handbook of Agriculture (pp. 1128-1164). Indian Council of Agricultural Research, New Delhi.

Purseglove, J. W. (1974). Tropical Crops: Dicotyledons (pp. 321-328). Longman Group Limited, London.

Reijntjes, C., B. Haverkort, B., \& Waters-Bayer, A. (1992). Farming for the Future: An Introduction of Low-External-Input. ETC/ILEIA. The Macmillan Press Ltd., London and Basingstoke.

Sambo, B. E. (2009). Influence of Intra-row Spacing, Clipping Height and Time on the Productivity of Dual Purpose Cowpea (Vigna unguiculata (L.) Walp) and Soil Fertility. A PhD Thesis, Department of Agronomy, Ahmadu Bello University, Zaria, Nigeria.

Sambo, B. E., \& Odion, E. C. (2011). Conservation-Organic Agriculture: Panacea for Enhanced Productivity, Soil Fertility Improvement, Income Growth and Sustainability in the Savannah Regions of Nigeria. Journal of Sustainable Development and Environmental Protection, 1(2), 123-134

Sambo, B. E., Odion, E. C., Aliyu, L., \& Labe, D. A. (2013). Cowpea (Vina unguiculata (L.) Walp) clipping management technology 1: A potential for fodder production, sustained growth and food security in the savannah regions of Nigeria. Journal of Agricultural and Crop Research, 1(3), 36-45.

Scholes, M. C., Swift, M. J., Hewal, O. W., Sanchez, P. A., \& Ingram, J. S. I. (1994). Soil Fertility Research in Response to the Demand for Sustainability. In P. L. Woomer, \& M. J. Swift (Eds.), The Biological Management of Tropical Soil Fertility (pp. 1-14). John Wiley \& Sons, New York. Tropical Soil Biology and Fertility Programme (TSBF) and Sayce Publishing (United Kingdom).

Singh, B. B., Mohan Raj, D. R., Dashiell, K. E., \& Jackai, L. E. N. (Eds.). (1997). Advances in Cowpea Research. Co-publication of International Institute of Tropical Agricultural Sciences (JIRCAS). IITA Ibadan, Nigeria.

Snedecor, G. W., \& Cochran, W. G. (1967). Statistical methods $6^{\text {th }}$ edition (p. 456). U.S.A.: Iowa State University Press.

Tian, G., Kang, B. T., Akobundu, I. O., \& Manyond, M. (1994). Food Production in the moist savanna of West and Central Africa. In B. T. Kang, I. O. Akobundu, V. M. Manyong, R. J. Carsky, N. Sanginga \& E. A. Kueneman (Eds.), Moist Savannas of Africa; Potentials and Constraints for Crop Production(pp. 107-127).. Proceedings of an IITA/FAO Workshop held from 19-23 September, 1994, Cotonou, Republic of Benin.

Webster, C. C., \& Wilson, P. N. (1980). Agriculture in the Tropics. Longman Group Ltd. London. pp. 640. In M. A. Badejo, \& A.O. Togun. Strategies and Tactics of Sustainable Agriculture in the Tropics. (Vol. 2, pp. 1-226). College Press and Publishers Ltd; Ibadan, Nigeria, 2004.

Willey, R. W., \& Osiru, D. S. O. (1972). Studies on Mixtures of Maize and Beans (Phaseolous vulgaris) with Particular Reference to Plant Population. Journal of Agricultural Science, 79, 517-529. http://dx.doi.org/10.1017/S0021859600025909

\section{Copyrights}

Copyright for this article is retained by the author(s), with first publication rights granted to the journal.

This is an open-access article distributed under the terms and conditions of the Creative Commons Attribution license (http://creativecommons.org/licenses/by/3.0/). 